\title{
Oxidative stress contributes to cobalt oxide nanoparticles-induced cytotoxicity and DNA damage in human hepatocarcinoma cells
}

This article was published in the following Dove Press journal:

International Journal of Nanomedicine

7 January 2013

Number of times this article has been viewed

\author{
Saud Alarifi' \\ Daoud Ali' \\ Al Omar Suliman $Y^{2}$ \\ Maqusood Ahamed ${ }^{3}$ \\ Maqsood A Siddiqui ${ }^{2}$ \\ Abdulaziz A Al-Khedhairy ${ }^{2}$ \\ 'Cell and Molecular Laboratory, \\ Department of Zoology, Faculty \\ of Science, King Saud University, \\ Riyadh, Saudi Arabia; ' ${ }^{2}$ Faculty of \\ Science, Department of Zoology, \\ King Saud University, Riyadh, Saudi \\ Arabia; ${ }^{3}$ King Abdullah Institute for \\ Nanotechnology, King Saud University, \\ Riyadh, Saudi Arabia
}

Background: Cobalt oxide nanoparticles $\left(\mathrm{Co}_{3} \mathrm{O}_{4} \mathrm{NPs}\right)$ are increasingly recognized for their utility in biological applications, magnetic resonance imaging, and drug delivery. However, little is known about the toxicity of $\mathrm{Co}_{3} \mathrm{O}_{4} \mathrm{NPs}$ in human cells.

Methods: We investigated the possible mechanisms of genotoxicity induced by $\mathrm{Co}_{3} \mathrm{O}_{4} \mathrm{NPs}$ in human hepatocarcinoma (HepG2) cells. Cell viability, reactive oxygen species (ROS), glutathione, thiobarbituric acid reactive substance, apoptosis, and DNA damage were assessed in HepG2 cells after $\mathrm{Co}_{3} \mathrm{O}_{4} \mathrm{NPs}$ and $\mathrm{Co}^{2+}$ exposure.

Results: $\mathrm{Co}_{3} \mathrm{O}_{4}$ NPs elicited a significant $(P<0.01)$ reduction in glutathione with a concomitant increase in lipid hydroperoxide, ROS generation, superoxide dismutase, and catalase activity after 24- and 48-hour exposure. $\mathrm{Co}_{3} \mathrm{O}_{4} \mathrm{NPs}$ had a mild cytotoxic effect in HepG2 cells; however, it induced ROS and oxidative stress, leading to DNA damage, a probable mechanism of genotoxicity. The comet assay showed a statistically significant $(P<0.01)$ dose- and time-related increase in DNA damage for $\mathrm{Co}_{3} \mathrm{O}_{4} \mathrm{NPs}$, whereas $\mathrm{Co}^{2+}$ induced less change than $\mathrm{Co}_{3} \mathrm{O}_{4} \mathrm{NPs}$ but significantly more than control.

Conclusion: Our results demonstrated that $\mathrm{Co}_{3} \mathrm{O}_{4} \mathrm{NPs}$ induced cytotoxicity and genotoxicity in HepG2 cells through ROS and oxidative stress.

Keywords: cobalt oxide nanoparticles, HepG2 cells, cytotoxicity, oxidative stress, DNA damage

The use of nanotechnology has seen an exponential growth in the areas of health care, consumer products, clothes, electronics, and sporting goods. ${ }^{1}$ This is due to the unique properties of nanomaterials (eg, chemical, mechanical, optical, magnetic, and biological), which make them desirable for commercial and medical applications. ${ }^{2,3}$ According to a recent survey, the number of nanotechnology-based consumer products available in the world market has crossed the 1000 mark. ${ }^{4}$ Thus, it is essential to assess the health hazards of nanomaterials in humans and other species. ${ }^{2}$ Metal nanoparticles exhibit unique properties in terms of optical, magnetic, and electrical activity. ${ }^{5}$ One of the most interesting chemical elements used as nanoparticles for biomedical applications is cobalt oxide nanoparticles $\left(\mathrm{Co}_{3} \mathrm{O}_{4} \mathrm{NPs}\right)$.

Occupational exposure of cobalt can lead to various lung diseases, such as interstitial pneumonitis, fibrosis, and asthma. ${ }^{6}$ De Boeck et al ${ }^{7}$ reported the genotoxic potential of cobalt nanoparticles in humans. A synergistic effect of cobalt and tungsten carbide enhanced production of reactive oxygen species (ROS) and induced DNA fragmentation. ${ }^{8}$ In view of their possible risk for human health as nanotechnology products, the cytotoxic and genotoxic effects $\mathrm{Co}_{3} \mathrm{O}_{4} \mathrm{NPs}$ are of concern.
Correspondence: Daoud Ali

Cell and Molecular Laboratory,

Department of Zoology, Faculty of Science, King Saud University, Box 2455, Riyadh II45I, Saudi Arabia Tel +96655890462

Email daudali.ksul2@yahoo.com 
ROS is an important factor in the apoptosis process as well as in DNA damage, ${ }^{9}$ oxidative stress-induced damage, and other cellular processes. However, the mechanisms involved in the toxicity of commercially important $\mathrm{Co}_{3} \mathrm{O}_{4}$ NPs are poorly understood. Human hepatocarcinoma (HepG2) cells have been used as a surrogate for human hepatocytes and have found application in the study of nanoparticle cytotoxicity. ${ }^{10}$ Subsequently, measurement of ROS with 2,7-dichlorfluorescein-diacetate (DCFH-DA) was carried out to determine whether ROS generation could be a possible mechanism in the observed cytotoxicity of $\mathrm{Co}_{3} \mathrm{O}_{4}$ NPs. In the presence of DNA damage or cellular stress, p53 protein triggers cell-cycle arrest to provide time for the damage to be repaired or for self-mediated apoptosis. ${ }^{11}$ Recent studies have shown that $\mathrm{Co}_{3} \mathrm{O}_{4} \mathrm{NPs}$ releases cobalt ions $\left(\mathrm{Co}^{2+}\right)$ in the aqueous state. Therefore, we also investigated whether $\mathrm{Co}_{3} \mathrm{O}_{4} \mathrm{NPs}$ induce a cellular response in HepG2 cells, and if so, whether they produce toxicity by releasing soluble $\mathrm{Co}^{2+}$ or by exerting a toxic effect unique to $\mathrm{Co}_{3} \mathrm{O}_{4} \mathrm{NPs}$.

The present investigations were carried out to study the underlying mechanisms of cytotoxicity and genotoxicity induced by $\mathrm{Co}_{3} \mathrm{O}_{4} \mathrm{NPs}$ in human hepatoma cells through ROS generation and oxidative stress.

\section{Materials and methods Chemicals and reagents}

Fetal bovine serum, penicillin-streptomycin, and Dulbeco's Modified Eagle's Medium: Nutrient Mixture F-12 (DMEM/ F-12) were purchased from Invitrogen (Carlsbad, CA, USA). $\mathrm{Co}_{3} \mathrm{O}_{4} \mathrm{NPs}$, glutathione (GSH), 5, 5-dithio-bis-(2nitrobenzoic acid), MTT [3-(4,5-dimethylthiazol-2-yl)-2,5diphenyltetrazoliumbromide], Dichlorofluorescin diacetate (DCFH-DA), and propidium iodide were obtained from Sigma-Aldrich (St Louis, MO, USA). Cobalt chloride and all other chemicals used were of high purity and available from commercial sources.

\section{$\mathrm{Co}_{3} \mathrm{O}_{4}$ nanoparticle preparation and characterization}

$\mathrm{Co}_{3} \mathrm{O}_{4} \mathrm{NPs}$ were suspended in Milli-Q water (EMD Millipore, Billerica, MA, USA) at a concentration of $1 \mathrm{mg} / \mathrm{mL}$. Stock suspension was probe sonicated at $40 \mathrm{~W}$ for 15 minutes. The optical absorption of the $\mathrm{Co}_{3} \mathrm{O}_{4} \mathrm{NPs}$ suspension was measured using a double beam ultraviolet-visible (UV-Vis) spectrum (Varian-Cary-300 UV-Vis Spectrophotometer, BioTech, MD, USA) in the wavelength range of $200-800 \mathrm{~nm}$ at room temperature. The average hydrodynamic size of the $\mathrm{Co}_{3} \mathrm{O}_{4} \mathrm{NPs}$ was measured by dynamic light scattering (DLS) (Nano-Zeta Sizer-HT; Malvern Instruments, Worecestershire, UK) following the procedure of Murdock et al. ${ }^{12}$

Samples for transmission electron microscopy (TEM) analysis were prepared by drop coating $\mathrm{Co}_{3} \mathrm{O}_{4} \mathrm{NP}$ solution on carbon-coated copper TEM grids. The films on the TEM grids were allowed to dry prior to measurement. TEM measurements were performed on a JEOL model 2100F (JEOL, Tokyo, Japan) operated at an accelerating voltage at $200 \mathrm{kV}$.

\section{Cell culture and exposure of $\mathrm{Co}_{3} \mathrm{O}_{4} \mathrm{NPs}$}

HepG2 (passage no 28) was procured from the American Type Culture Collection (Accession no HB-8065; Rockville, MD, USA) and was preserved and subcultured up to passage no 40 in the laboratory. The subcultures were used to determine cell viability against $\mathrm{Co}_{3} \mathrm{O}_{4} \mathrm{NPs}$ and $\mathrm{Co}^{2+}$ exposure. Cells were cultured in DMEM/F-12 medium supplemented with $10 \%$ fetal bovine serum and $100 \mathrm{U} / \mathrm{mL}$ penicillin-streptomycin at $5 \% \mathrm{CO}_{2}$ and $37^{\circ} \mathrm{C}$. At $85 \%$ confluence, cells were harvested by using $0.25 \%$ trypsin and were subcultured into $75 \mathrm{~cm}^{2}$ flasks, 6-well plates, or 96-well plates according to the type of experiment. Cells were allowed to attach to the surface for 24 hours prior to treatment. $\mathrm{Co}_{3} \mathrm{O}_{4} \mathrm{NPs}$ were suspended in cell culture medium and diluted to appropriate concentrations $(0,5,10,15$, and $25 \mu \mathrm{g} / \mathrm{mL}$ ). The appropriate dilutions of $\mathrm{Co}_{3} \mathrm{O}_{4} \mathrm{NPs}$ were then sonicated in a sonicator bath at room temperature for 10 minutes at $40 \mathrm{~W}$ to avoid particle agglomeration before exposure to cells. Cells not exposed to $\mathrm{Co}_{3} \mathrm{O}_{4} \mathrm{NPs}$ served as the control in each experiment.

\section{Analysis of dissolution of $\mathrm{Co}_{3} \mathrm{O}_{4} \mathrm{NPs}$}

Dissolution of $\mathrm{Co}_{3} \mathrm{O}_{4} \mathrm{NPs}$ and the effects from exposure to cells were analyzed to determine whether $\mathrm{Co}^{2+}$ released from $\mathrm{Co}_{3} \mathrm{O}_{4} \mathrm{NP}$ suspension may play a role in cellular toxicity. The released $\mathrm{Co}^{2+}$ concentrations were measured in all the culture media collected from the $\mathrm{Co}_{3} \mathrm{O}_{4} \mathrm{NP}$ treatment. Culture media were taken from the $\mathrm{Co}_{3} \mathrm{O}_{4} \mathrm{NP}$-treated cells immediately at the end of exposure and centrifuged at $30,000 \mathrm{~g}$ for 30 minutes. After centrifugation, the released $\mathrm{Co}^{2+}$ concentrations in the supernatants were detected by flame atomic absorption spectroscopy (GBC Avanta Ver 2.0; Sigma-Aldrich).

To compare the toxic effects of released $\mathrm{Co}^{2+}$ with $\mathrm{Co}_{3} \mathrm{O}_{4} \mathrm{NPs}$, another exposure regime with soluble $\mathrm{Co}^{2+}$ was 
performed. The $\mathrm{Co}_{3} \mathrm{O}_{4} \mathrm{NPs}$ suspension was replaced by $\mathrm{Co}^{2+}$ solution $(10,15$, and $25 \mu \mathrm{g} / \mathrm{mL}$ ), which was dosed by adding the required mass of cobalt chloride $(97.0 \%-100 \%, \mathrm{BDH}$ Chemicals, Radnor, PA, USA) to the culture medium.

\section{Cell morphology}

Morphology of the HepG2 cells was observed after exposure to different concentrations of $\mathrm{Co}_{3} \mathrm{O}_{4} \mathrm{NPs}$ for 24 and 48 hours by using a Leica DMIL phase-contrast microscope (Leica Microsystems, Wetzlar, Germany).

\section{Mitochondrial function}

The MTT assay was used to investigate mitochondrial function as described by Mossman. ${ }^{13}$ Briefly, $1 \times 10^{4}$ cells/ well were seeded in 96-well plates and exposed to different concentrations of $\mathrm{Co}_{3} \mathrm{O}_{4} \mathrm{NPs}$ and $\mathrm{Co}^{2+}$ for 24 and 48 hours. At the end of exposure, culture media was replaced with new media containing MTT solution $(0.5 \mathrm{mg} / \mathrm{mL})$ and incubated for 4 hours at $37^{\circ} \mathrm{C}$. As a result, formazan crystal was formed, which was dissolved in Dimethyl sulfoxide (DMSO). The plates were kept on a shaker for 10 minutes at room temperature and then analyzed at $530 \mathrm{~nm}$ with a multiwell microplate reader (Omega Fluostar, BMG Labtech GmbH, Allmendgruen, Germany). Untreated sets were also run under identical conditions and served as control.

\section{Lactate dehydrogenase leakage assay}

The release of cytoplasmic lactate dehydrogenase enzyme (LDH) into the culture medium was determined following Wroblewski and LaDue. ${ }^{14}$ HepG2 cells were treated with different concentrations of $\mathrm{Co}_{3} \mathrm{O}_{4} \mathrm{NPs}$ and $\mathrm{Co}^{2+}$ for 24 and 48 hours. After exposure, $100 \mu \mathrm{L}$ samples from the centrifuged culture media were collected. The LDH activity was assayed in $3.0 \mathrm{~mL}$ of reaction mixture with $100 \mu \mathrm{L}$ of pyruvic acid $(2.5 \mathrm{mg} / \mathrm{mL}$ phosphate buffer) and $100 \mu \mathrm{L}$ of reduced nicotinamide adenine dinucleotide (NADH) $(2.5 \mathrm{mg} / \mathrm{mL}$ phosphate buffer); the rest of the volume was adjusted with phosphate buffer $(0.1 \mathrm{M}, \mathrm{pH} 7.4)$. The rate of NADH oxidation was determined by following the decrease in absorbance at $340 \mathrm{~nm}$ for 3 minutes at 1 -minute intervals at $25^{\circ} \mathrm{C}$ using a spectrophotometer (Varian-Cary 300 Bio).The amount of LDH released was expressed as LDH activity (IU/L) in culture media.

\section{Measurement of intracellular ROS}

We used fluorometric analysis and microscopic fluorescence imaging to study ROS generation in HepG2 cells after expo- sure to different concentrations of $\mathrm{Co}_{3} \mathrm{O}_{4} \mathrm{NPs}$ and $\mathrm{Co}^{2+} .{ }^{15}$ For fluorometric analysis, cells $\left(1 \times 10^{4}\right.$ per well $)$ were seeded in 96-well black bottom culture plates and allowed to adhere for 24 hours in a $\mathrm{CO}_{2}$ incubator at $37^{\circ} \mathrm{C}$. HepG2 cells were then exposed to 5,10 , and $15 \mu \mathrm{g} / \mathrm{mL}$ concentrations of $\mathrm{Co}_{3} \mathrm{O}_{4} \mathrm{NPs}$ and $\mathrm{Co}^{2+}$ for 24 and 48 hours. After exposure, cells were incubated with DCFH-DA $(10 \mathrm{mM})$ as the fluorescence agent for 30 minutes at $37^{\circ} \mathrm{C}$. The reaction mixture was aspirated and replaced by $200 \mu \mathrm{L}$ of phosphate-buffered saline (PBS) in each well. The plates were kept on a shaker for 10 minutes at room temperature in the dark. Fluorescence intensity was measured with a multiwell microplate reader (Omega Fluostar) at an excitation wavelength of $485 \mathrm{~nm}$ and at an emission wavelength of $528 \mathrm{~nm}$. Values were expressed as the percentage of fluorescence intensity relative to the control wells.

An upright fluorescence microscope equipped with a CCD cool camera (Nikon Eclipse 80i with Nikon DS-Ri1 12.7 megapixel camera; Nikon Corporation, Tokyo Japan) was used to analyze intracellular fluorescence of a second set of cells $\left(5 \times 10^{4}\right.$ per well $)$ prepared as described above.

\section{Oxidative stress biomarkers}

Cells at a final density of $\sim 6 \times 10^{6}$ in a $75 \mathrm{~cm}^{2}$ culture flask were exposed to different concentrations of $(5,10$ and $15 \mu \mathrm{g} / \mathrm{mL})$ of $\mathrm{Co}_{3} \mathrm{O}_{4} \mathrm{NPs}$ and $\left(10\right.$ and $15 \mu \mathrm{g} / \mathrm{mL}$ ) of $\mathrm{Co}^{2+}$ for 24 and 48 hours. After exposure, the cells were scraped and washed twice with chilled $1 \times$ PBS. The harvested cell pellets were lysed in cell lysis buffer (20 mM Tris- $\mathrm{HCl}$ [pH 7.5], $150 \mathrm{mM} \mathrm{NaCl}, 1 \mathrm{mM}$ $\mathrm{Na}_{2} \mathrm{EDTA}, 1 \%$ Triton, and $2.5 \mathrm{mM}$ sodium pyrophosphate). The cells were centrifuged at $15,000 \mathrm{~g}$ for 10 minutes at $4{ }^{\circ} \mathrm{C}$, and the supernatant (cell extract) was maintained on ice until assayed for oxidative-stress biomarkers. Protein content was measured by the method of Bradford, ${ }^{16}$ using bovine serum albumin as the standard.

\section{Lipid peroxidation assay}

The extent of membrane lipid peroxidation (LPO) was estimated by measuring the formation of malondialdehyde (MDA), one of the products of membrane LPO, using the method of Ohkawa et al. ${ }^{17} \mathrm{~A}$ mixture of $0.1 \mathrm{~mL}$ cell extract and $1.9 \mathrm{~mL}$ of $0.1 \mathrm{M}$ sodium phosphate buffer ( $\mathrm{pH} 7.4$ ) was incubated at $37^{\circ} \mathrm{C}$ for 1 hour. After precipitation with $5 \%$ trichloroacetic acid, the incubation mixture was centrifuged at $2300 \mathrm{~g}$ for 15 minutes at room temperature. One milliliter of $1 \%$ thiobarbituric was added to the supernatant, which was then placed in boiling water for 15 minutes. After cooling to room temperature, absorbance of the mixture at $532 \mathrm{~nm}$ 
was expressed in nmol MDA/hour/mg protein using a molar extinction coefficient of $1.56 \times 105 / \mathrm{M} / \mathrm{cm}$.

\section{GSH estimation}

GSH level was quantified by using Ellman's reagent. ${ }^{18}$ The assay mixture contained phosphate buffer, DTNB, and cell extract. The reaction was monitored at $412 \mathrm{~nm}$, and the amount of GSH was expressed in terms of nmol GSH/mg protein.

\section{Measurement of superoxide dismutase}

Superoxide dismutase (SOD) activity was estimated using a method described by Kakkar et al. ${ }^{19}$ The assay mixture contained sodium pyrophosphate buffer, nitroblue tetrazolium, phenazine methosulphate, reduced nicotinamide adenine dinucleotide, and the required volume of cell extract. One unit of SOD enzyme activity is defined as the amount of enzyme required for inhibiting chromogen production (optical density at $560 \mathrm{~nm}$ ) by $50 \%$ in 1 minute under assay conditions and is expressed as specific activity in units/ minute/mg protein.

\section{Measurement of catalase level}

Catalase (CAT) activity was measured by following its ability to split hydrogen peroxide $\left(\mathrm{H}_{2} \mathrm{O}_{2}\right)$ within 1 minute of incubation time. The reaction was then stopped by adding dichromate/acetic acid reagent, and the remaining $\mathrm{H}_{2} \mathrm{O}_{2}$ was determined by measuring chromic acetate at $570 \mathrm{~nm}$. Chromic acetate is formed by the reduction of dichromate/ acetic acid in the presence of $\mathrm{H}_{2} \mathrm{O}_{2}$, as described by Sinha. ${ }^{20}$ CAT activity was expressed as $\mu \mathrm{M} \mathrm{H}_{2} \mathrm{O}_{2}$ decomposition/ minute/mg protein.

\section{Caspase- 3 assay}

The activity of caspase- 3 was determined from the cleavage of the caspase-3 substrate (N-acetyl-DEVD-p-nitroaniline). p-Nitroaniline was used as the standard. Cleavage of the substrate was monitored at $405 \mathrm{~nm}$, and the specific activity was expressed as pM of the product (nitroaniline) per minute/mg protein.

\section{DAPI staining for chromosome condensation}

Chromosome condensation in HepG2 cells due to $\mathrm{Co}_{3} \mathrm{O}_{4} \mathrm{NPs}$ and $\mathrm{Co}^{2+}$ was observed by DAPI staining according to the method of Dhar-Mascareno et al. ${ }^{21}$ Cells were placed in eight chamber slides, which were incubated in the DAPI solution for 10 minutes in the dark at $37^{\circ} \mathrm{C}$. Images of the nucleus were captured by fluorescence microscopy (Nikon) at an excitation wavelength of $330 \mathrm{~nm}$ and an emission wavelength of $420 \mathrm{~nm}$.

\section{Determination of DNA strand breakage}

Alkaline single cell gel electrophoresis was performed as a three-layer procedure ${ }^{22}$ with slight modification. ${ }^{23}$ In brief, 70,000 cells/well were seeded in a six-well plate. After 24 hours, cells were treated with different concentrations of $\mathrm{Co}_{3} \mathrm{O}_{4} \mathrm{NPs}$ and $\mathrm{Co}^{2+}$ for 24 and 48 hours. After treatment, the HepG2 cells were trypsinized and resuspended in DMEM, and the cell suspension was centrifuged at $1200 \mathrm{rpm}$ at $4^{\circ} \mathrm{C}$ for 5 minutes. The cell pellet was then suspended in chilled PBS for the comet assay. Viability of cells was evaluated by the trypan blue exclusion method. ${ }^{24}$ Samples showing cell viability higher than $84 \%$ were further processed for the comet assay. In brief, about $15 \mu \mathrm{L}$ of cell suspension $(\sim 20,000$ cells $)$ was mixed with $85 \mu \mathrm{L}$ of $0.5 \%$ low-melting-point agarose and layered on one end of a frosted plain glass slide, precoated with a layer of $200 \mu \mathrm{L}$ normal agarose $(1 \%)$. The sample was then covered with a third layer of $100 \mu \mathrm{L}$ low-melting-point agarose. After solidification of the gel, the slides were immersed in lysing solution (2.5 M NaCl, $100 \mathrm{mM} \mathrm{Na} 2$ EDTA, $10 \mathrm{mM}$ Tris [pH 10] with10\% DMSO, and 1\% Triton X-100 [added fresh]) overnight at $4^{\circ} \mathrm{C}$. The slides were then placed in a horizontal gel electrophoresis unit. Fresh cold alkaline electrophoresis buffer ( $300 \mathrm{mM} \mathrm{NaOH}, 1 \mathrm{mM} \mathrm{Na}{ }_{2}$ EDTA, and $0.2 \%$ DMSO), $\mathrm{pH} 13.5$, was poured into the chamber and left for 20 minutes at $4^{\circ} \mathrm{C}$ for DNA unwinding and conversion of alkali-labile sites to single-strand breaks. Electrophoresis was carried out using the same solution at $4^{\circ} \mathrm{C}$ for 20 minutes at $15 \mathrm{~V}(0.8 \mathrm{~V} / \mathrm{cm})$ and $300 \mathrm{~mA}$. The slides were neutralized gently with $0.4 \mathrm{M}$ tris buffer at pH 7.5 and stained with $75 \mu \mathrm{L}$ ethidium bromide $(20 \mu \mathrm{g} /$ $\mathrm{mL}$ ). For the positive control, the HepG2 cells were treated with $100 \mu \mathrm{M} \mathrm{H}_{2} \mathrm{O}_{2}$ for 10 minutes at $4^{\circ} \mathrm{C}$. Two slides were prepared from each well (per concentration), and 50 cells per slide ( 100 cells per concentration) were scored randomly and analyzed using an image analysis system (Komet-5.0; Kinetic Imaging, Liverpool, UK) attached to fluorescence microscope (DMLB, Leica, Germany) equipped with appropriate filters. The parameters, percent tail DNA ( $\%$ tail DNA $=100-\%$ head DNA) and olive tail moment, were selected for quantification of DNA damage in HepG2 cells as determined by the software (Komet-5.0; Kinetic Imaging, Liverpool, UK). 

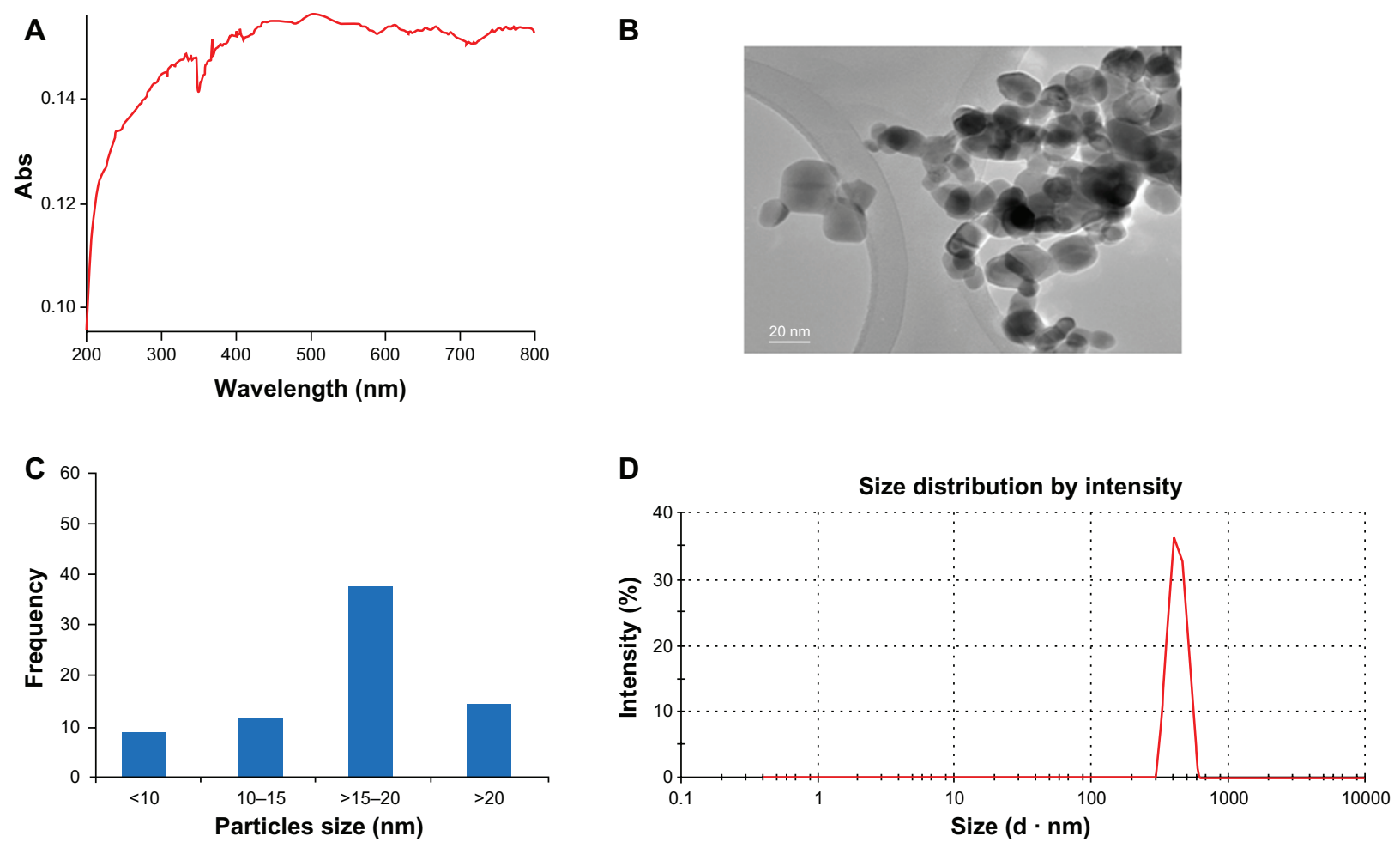

Figure I Characterization of $\mathrm{Co}_{3} \mathrm{O}_{4} \mathrm{NPs}$. (A) UV-visible spectrum of $\mathrm{Co}_{3} \mathrm{O}_{4} \mathrm{NPs}$. (B) TEM image. (C) Size distribution histogram generated by using a TEM image. (D) Size distribution and zeta potential of $\mathrm{Co}_{3} \mathrm{O}_{4} \mathrm{NPs}$ were determined using dynamic light scattering.

Note: Analysis was performed from the stock solution.

Abbreviations: Abs, absorbance; $\mathrm{CO}_{3} \mathrm{O}_{4} \mathrm{NPs}$, cobalt oxide nanoparticles; TEM, transmission electron microscopy.

\section{Statistical analysis}

At least three independent experiments were carried out in duplicate for each experiment. Data were expressed as mean ( \pm standard error) and analyzed by one-way analysis of variance. $P<0.01$ was considered statistically significant.

\section{Results}

\section{Physicochemical characterization of $\mathrm{Co}_{3} \mathrm{O}_{4} \mathrm{NPs}$}

Results from the UV-Vis spectrophotometer showed an absorption band (Figure 1A). A typical TEM image of the
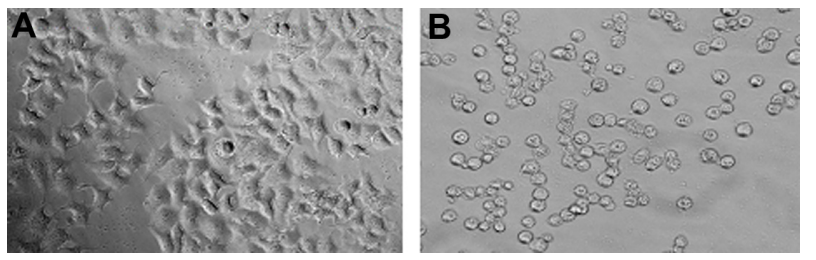

Figure 2 Morphology of HepG2 cells. (A) Control; (B) $25 \mu \mathrm{g} / \mathrm{mL}$ of $\mathrm{Co}_{3} \mathrm{O}_{4} \mathrm{NPs}$ treated for 48 hours.

Note: Magnification 200x.

Abbreviations: HepG2, human hepatocarcinoma; $\mathrm{Co}_{3} \mathrm{O}_{4} \mathrm{NPs}$, cobalt oxide nanoparticles.
$\mathrm{Co}_{3} \mathrm{O}_{4} \mathrm{NPs}$ (Figure 1B) showed that the majority of particles had a polygonal shape with smooth surfaces. The average particle diameter of approximately $21 \mathrm{~nm}$ was calculated from measuring over 100 particles in random fields of TEM view (Figure 1C). The average hydrodynamic size and zeta potential of the $\mathrm{Co}_{3} \mathrm{O}_{4} \mathrm{NPs}$ in water determined by DLS were $264.8 \mathrm{~nm}$ and $-15.3 \mathrm{mV}$, respectively (Figure 1D).

\section{Effect of $\mathrm{Co}_{3} \mathrm{O}_{4} \mathrm{NPs}$ on morphological changes and cytotoxicity}

Figure 2 shows the comparative morphology of untreated and $\mathrm{Co}_{3} \mathrm{O}_{4} \mathrm{NPs}$-treated HepG2 cells. Morphological changes in cells were visible after $10 \mu \mathrm{g} / \mathrm{mL} \mathrm{Co}_{3} \mathrm{O}_{4} \mathrm{NPs}$ exposure in 24 hours. Cells treated with $25 \mu \mathrm{g} / \mathrm{mL} \mathrm{Co}_{3} \mathrm{O}_{4} \mathrm{NPs}$ after 48 hours changed to a spherical shape and detached from the surface (Figure 1B). The morphology of the HepG2 cells exposed to $\mathrm{Co}_{3} \mathrm{O}_{4} \mathrm{NPs}$ supported the results showing membrane damage and cytotoxicity.

We examined the mitochondrial function (MTT reduction) and membrane damage (LDH leakage) as cytotoxicity end points. MTT results demonstrated a concentration and time-dependent cytotoxicity after exposure to $\mathrm{Co}_{3} \mathrm{O}_{4} \mathrm{NPs}$ 

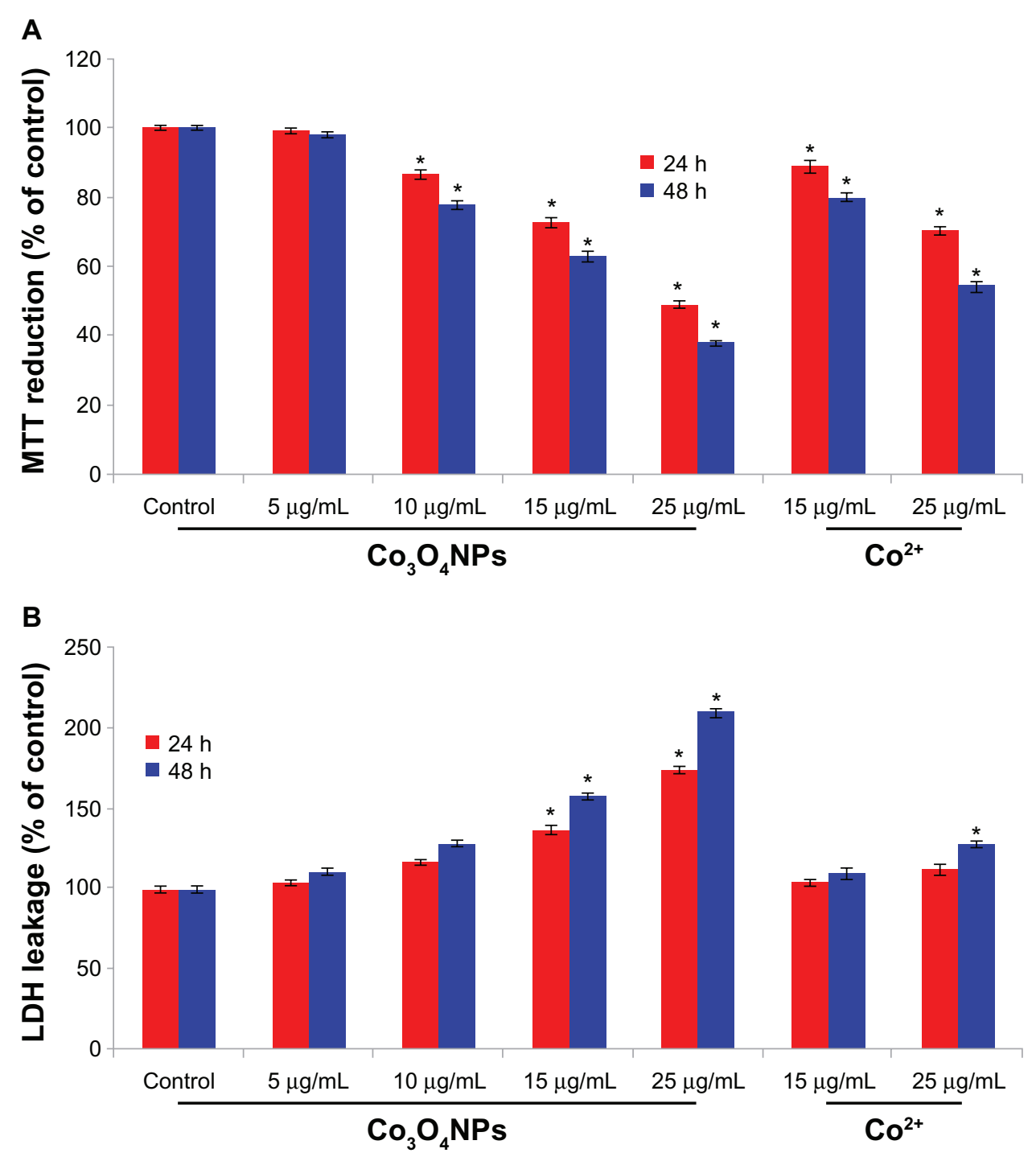

Figure 3 Cytotoxicity of $\mathrm{Co}_{3} \mathrm{O}_{4} \mathrm{NPs}$ and $\mathrm{Co}^{2+}$ in $\mathrm{HepG} 2$ cells for 24 hours and 48 hours. (A) MTT reduction; (B) LDH leakage.

Notes: Each value represents the mean \pm standard error of three experiments, performed in duplicate. $* P<0.0$ l vs control.

Abbreviations: $\mathrm{Co}_{3} \mathrm{O}_{4} \mathrm{NPs}$, cobalt oxide nanoparticles; $\mathrm{Co}^{2+}$, cobalt ions; HepG2, human hepatocarcinoma; MTT, 3-(4,5-dimethylthiazol-2-yl)-2,5-diphenyltetrazoliumbromide; $\mathrm{LDH}$, lactate dehydrogenase enzyme.

in HepG2 cells (Figure 3A). MTT reduction observed after 24 hours of exposure at concentrations of $5,10,15$, and $25 \mu \mathrm{g} / \mathrm{mL}$ was $1.6 \%, 10.0 \%, 30.7 \%$, and $46.0 \%$, respectively, with a further reduction to $3.4 \%, 24.61 \%, 36 \%$, and $62 \%$ after 48 hours exposure. $\mathrm{Co}_{3} \mathrm{O}_{4} \mathrm{NPs}$ was also found to induce LDH leakage in a concentration- and time-dependent manner (Figure 3B).

\section{$\mathrm{Co}_{3} \mathrm{O}_{4} \mathrm{NPs}$ induced ROS generation and oxidative stress}

The ability of $\mathrm{Co}_{3} \mathrm{O}_{4} \mathrm{NPs}$ to induce oxidative stress was evaluated by measuring the levels of ROS, LPO, GSH,
SOD, and catalase in HepG2 cells. Results showed that $\mathrm{Co}_{3} \mathrm{O}_{4} \mathrm{NPs}$ induced intracellular ROS generation in a doseand time-dependent manner (Figure 4). $\mathrm{Co}_{3} \mathrm{O}_{4} \mathrm{NPs}$-induced oxidative stress was further evidenced by depletion of GSH and induction of LPO, SOD, and catalase with concentration and time of $\mathrm{Co}_{3} \mathrm{O}_{4} \mathrm{NPs}$ exposure (Figure 5A-D).

\section{Induction of caspase-3 activity and chromosome condensation by $\mathrm{Co}_{3} \mathrm{O}_{4} \mathrm{NPs}$}

Caspase-3, which plays a key role in the apoptotic pathway of cells, was induced following treatment with $\mathrm{Co}_{3} \mathrm{O}_{4} \mathrm{NPs}$ 

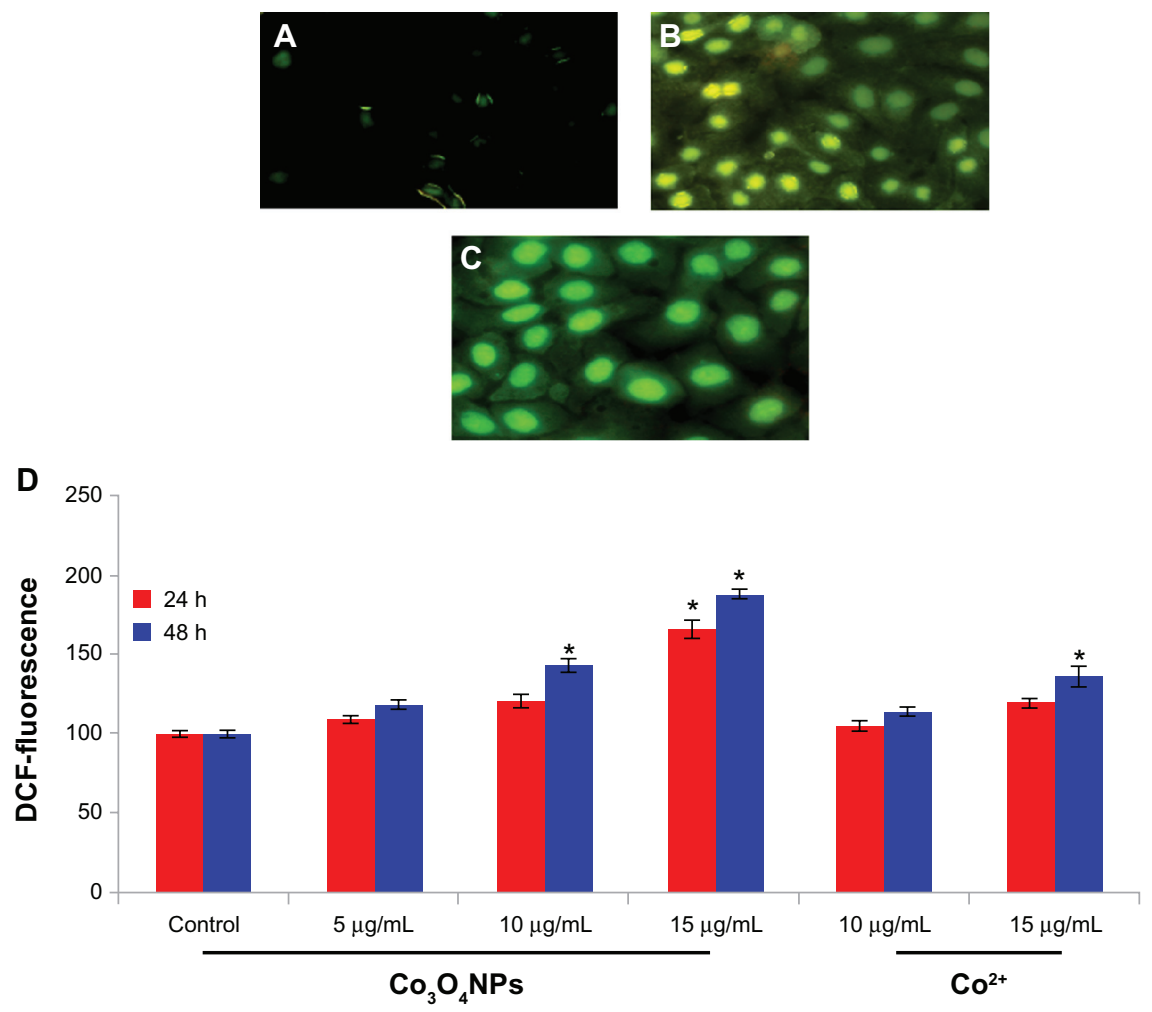

Figure 4 Representative microphotographs showing $\mathrm{Co}_{3} \mathrm{O}_{4} \mathrm{NP}$ - and $\mathrm{Co}^{2+}$-induced ROS generation in HepG2 cells. Images were snapped with Nikon phase contrast with a fluorescence microscope. (A) Control; (B) $15 \mu \mathrm{g} / \mathrm{mL}$ of $\mathrm{Co}^{2+}$; (C) $15 \mu \mathrm{g} / \mathrm{mL}$ of $\mathrm{Co}_{3} \mathrm{O}_{4} \mathrm{NPs}$; (D) percentage change in ROS generation after 24 and 48 hours exposure to various concentrations of $\mathrm{Co}_{3} \mathrm{O}_{4} \mathrm{NPs}$ and $\mathrm{Co}^{2+}$ in $\mathrm{HepG} 2$ cells.

Notes: Each value represents the mean \pm standard error of three experiments, performed in duplicate. $* P<0.01$ vs control.

Abbreviations: $\mathrm{Co}_{3} \mathrm{O}_{4} \mathrm{NPs}$, cobalt oxide nanoparticles; $\mathrm{Co}^{2+}$, cobalt ions; ROS, reactive oxygen species; HepG2, human hepatocarcinoma.

(Figure 6D). When cells were treated with 5, 10, and $15 \mu \mathrm{g} / \mathrm{mL}$ concentrations of $\mathrm{Co}_{3} \mathrm{O}_{4} \mathrm{NPs}$ for 24 and 48 hours, caspase- 3 activity increased in a concentration- and timedependent manner. In addition to the caspase-3 activity, chromatin condensation was also evaluated by DAPI staining. When cells were treated with the above concentrations of $\mathrm{Co}_{3} \mathrm{O}_{4} \mathrm{NPs}$ for 24 hours, chromatin condensation was observed in the treated group (Figure 6A-C). Caspase-3 activation and chromatin condensation in HepG2 cells suggest that $\mathrm{Co}_{3} \mathrm{O}_{4} \mathrm{NPs}$ caused cell death by an apoptotic process.

\section{DNA damage by $\mathrm{Co}_{3} \mathrm{O}_{4} \mathrm{NPs}$}

DNA damage was measured as percentage tail DNA and olive tail moment in the control as well as exposed cells. During electrophoresis, cell DNA was observed to migrate more rapidly toward the anode at the highest concentration compared to the lowest concentration. The cells exposed to different concentrations of $\mathrm{Co}_{3} \mathrm{O}_{4} \mathrm{NPs}$ exhibited significantly $(P>0.01)$ higher DNA damage than those of the control groups. A gradual nonlinear increase in DNA damage was observed in cells as dose and time of $\mathrm{Co}_{3} \mathrm{O}_{4} \mathrm{NPs}$ exposure increased. The highest DNA damage was recorded at $15 \mu \mathrm{g} / \mathrm{mL} \mathrm{Co} \mathrm{Co}_{3} \mathrm{NPs}$ in HepG2 cells (Figure 7).

\section{Dissolution of $\mathrm{Co}_{3} \mathrm{O}_{4} \mathrm{NPs}$ into $\mathrm{Co}^{2+}$ and effects of soluble $\mathrm{Co}^{2+}$ on cytotoxicity, oxidative stress, apoptosis markers, and DNA damage}

To determine whether our observed cytotoxicity, oxidative stress, apoptosis and DNA damage could be attributed to the released $\mathrm{Co}^{2+}$, we analyzed the level of $\mathrm{Co}^{2+}$ released from $\mathrm{Co}_{3} \mathrm{O}_{4} \mathrm{NPs}$ and tested the effect of $\mathrm{Co}^{2+}$ concentration in HepG2 cells. The highest released $\mathrm{Co}^{2+}$ concentration in the $\mathrm{Co}_{3} \mathrm{O}_{4} \mathrm{NP}$ suspension following exposure was $0.86 \pm 0.28 \mu \mathrm{g} / \mathrm{mL}$ in the $25 \mu \mathrm{g} / \mathrm{mL} \mathrm{Co}_{3} \mathrm{O}_{4} \mathrm{NP}$ suspension. The released $\mathrm{Co}^{2+}$ concentrations in 5,10 , and $15 \mu \mathrm{g} / \mathrm{mL}$ $\mathrm{Co}_{3} \mathrm{O}_{4} \mathrm{NPs}$ treatments were $0.14 \pm 0.06,0.39 \pm 0.23$, and $0.48 \pm 0.337 \mu \mathrm{g} / \mathrm{mL}$, respectively. Our data on the dissolution of $\mathrm{Co}_{3} \mathrm{O}_{4} \mathrm{NPs}$ in the aqueous state are in agreement with other recent studies (Papis et $\mathrm{al}^{25}$ ). We examined 
A

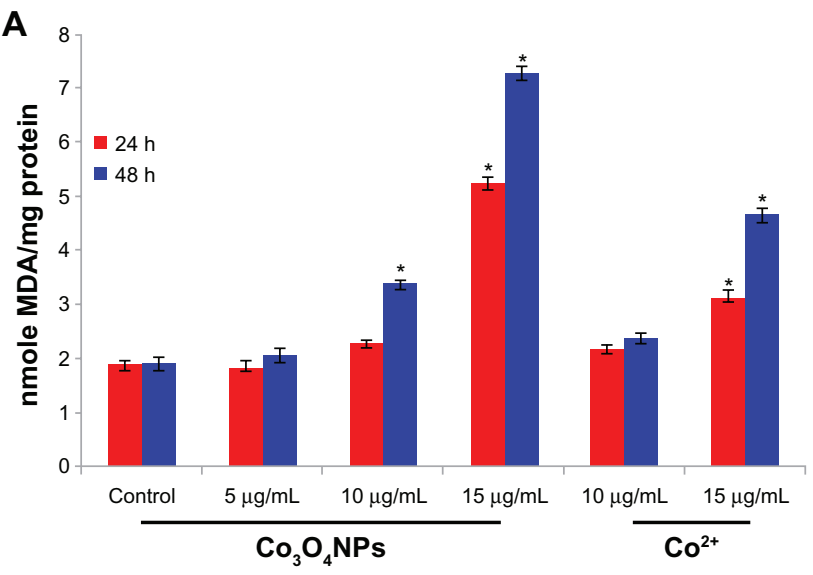

C

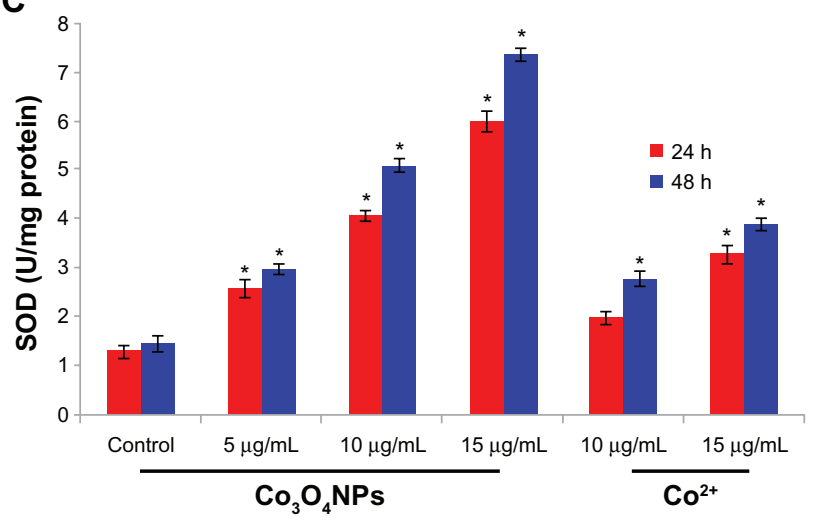

B

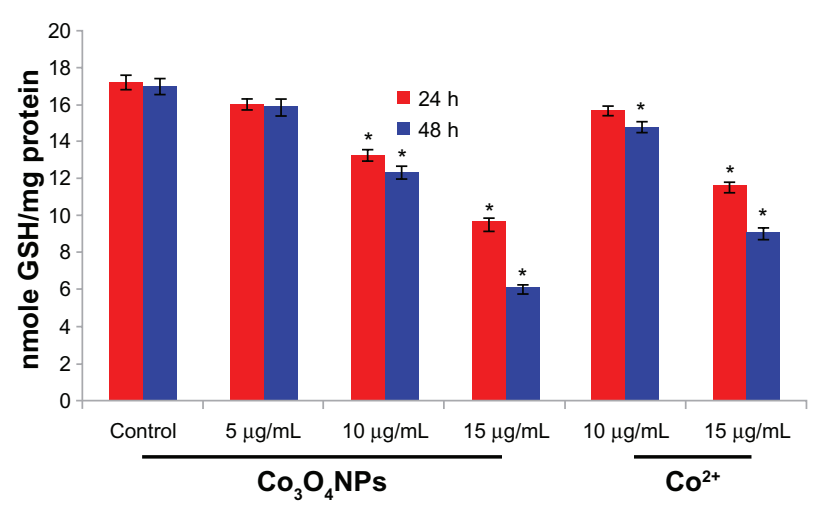

D

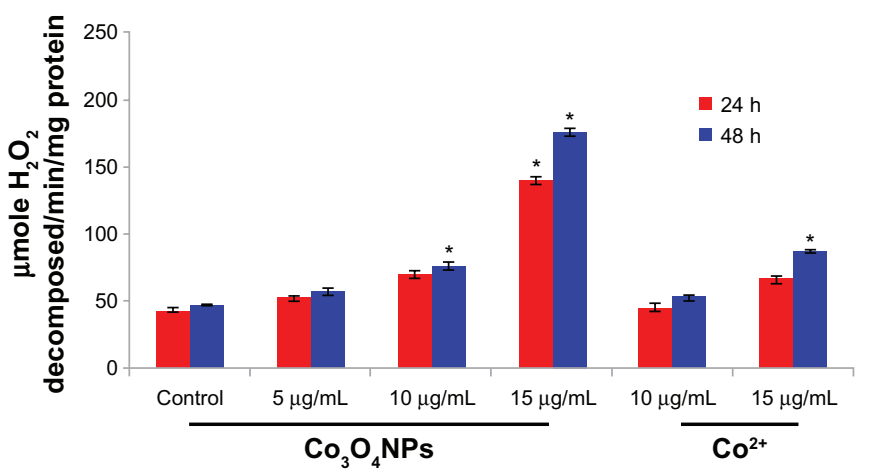

Figure 5 (A) Levels of lipid peroxides; (B) GSH; (C) SOD; (D) catalase in $\mathrm{HepG} 2$ cells after exposure of $\mathrm{Co}_{3} \mathrm{O}_{4} \mathrm{NPs}$ and $\mathrm{Co}^{2+}$ for 24 and 48 hours. Notes: Each value represents the mean \pm standard error of three experiments, performed in duplicate. $* P<0.0 \mathrm{I}$ vs control.

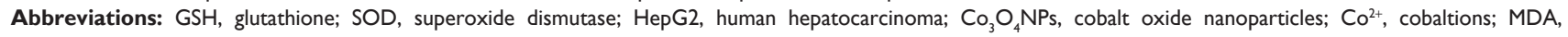
malondialdehyde.

the toxic effect of 10,15 , and $25 \mu \mathrm{g} / \mathrm{mL}$ of soluble $\mathrm{Co}^{2+}$ in HepG2 cells and found that $\mathrm{Co}^{2+}$ exerted cytotoxicity (MTT reduction and LDH leakage), oxidative stress (ROS, LPO, GSH, CAT, and SOD), apoptosis (caspase-3 and chromatin condensation), and DNA damage, but effects were less significant compared to similar concentrations of $\mathrm{Co}_{3} \mathrm{O}_{4} \mathrm{NPs}$, as shown in Figures 2-7.

\section{Discussion}

Cobalt-based NPs are used in different types of technological products, such as sensors, catalysts, and energy storage devices. ${ }^{26}$ HepG2 cells retain the function of fully differentiated primary hepatocytes and are widely used as a model system for hepatotoxicity studies. ${ }^{27}$ Recent studies showed that $\mathrm{Co}^{2+}$ is released from $\mathrm{Co}_{3} \mathrm{O}_{4} \mathrm{NPs}$ when they are suspended in the aqueous state. ${ }^{28}$ In the present study, we examined the dissolution of $\mathrm{Co}_{3} \mathrm{O}_{4} \mathrm{NPs}$ in an aqueous suspension and their toxicity to HepG2 cells. Our results agree with the findings of Colognato et $\mathrm{al}^{29}$ in which they reported that $\mathrm{Co}_{3} \mathrm{O}_{4} \mathrm{NPs}$ liberate $\mathrm{Co}^{2+}$ in the aqueous state, but the level of $\mathrm{Co}^{2+}$ was insufficient to induce cell toxicity. We used MTT and LDH assays to evaluate the cytotoxicity of $\mathrm{Co}_{3} \mathrm{O}_{4} \mathrm{NPs}$ in order to obtain more reliable data. MTT and LDH assays are frequently utilized to determine the cytotoxicity of nanoparticles in cell culture systems. ${ }^{30,31}$ Both assays demonstrated that $\mathrm{Co}_{3} \mathrm{O}_{4} \mathrm{NPs}$ produce significant cytotoxicity to $\mathrm{HepG} 2$ cells in a dose- and time-dependent manner.

Oxidative stress has been suggested as playing an important role in the mechanism of toxicity for a number of nanoparticles through either the excessive generation of ROS or depletion of cellular antioxidant capacity. ${ }^{32}$ ROS typically include the superoxide radical $\left(\mathrm{O}^{2-}\right), \mathrm{H}_{2} \mathrm{O}_{2}$, and the hydroxyl radical $(\cdot \mathrm{OH})$, all of which cause damage to cellular components, including DNA damage, and ultimately apoptotic cell death. ${ }^{33}$ In the present study, $\mathrm{Co}_{3} \mathrm{O}_{4} \mathrm{NPs}$ significantly altered oxidant/antioxidant levels in $\mathrm{HepG} 2$ cells. Generation of ROS, LPO, SOD, and catalase activities increased, while the antioxidant molecule GSH significantly declined in $\mathrm{Co}_{3} \mathrm{O}_{4} \mathrm{NP}$-exposed cells. GSH, a ubiquitous and abundant cellular antioxidant tripeptide, has been shown to 

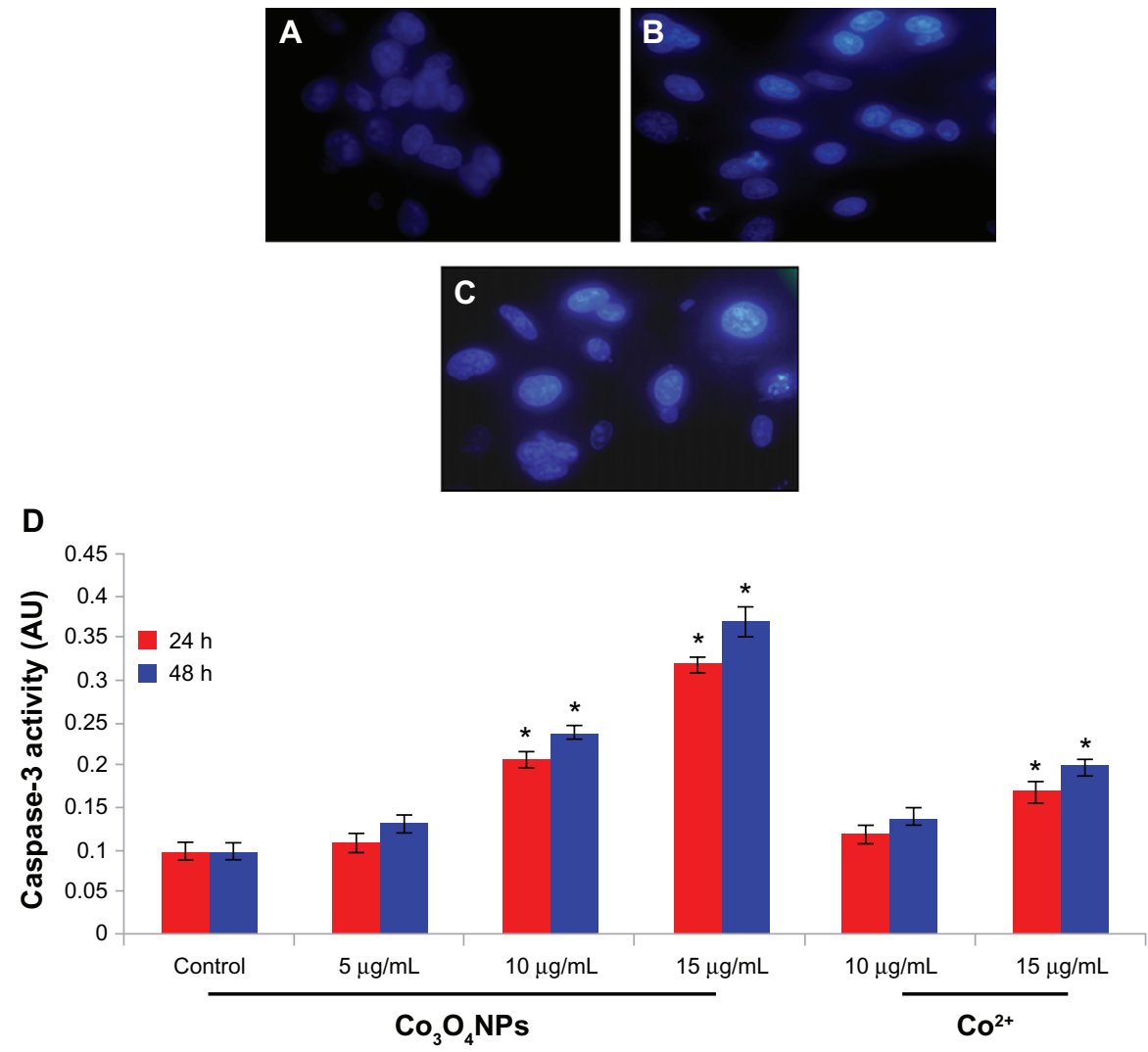

Figure 6 Increase of chromosome condensation and caspase-3 activity in HepG2 cells after exposure of $\mathrm{Co}_{3} \mathrm{O}_{4} \mathrm{NPs}_{\mathrm{s}}$ and $\mathrm{Co}^{2+}$ for 24 and 48 hours. (A) Control; (B) exposed to $15 \mu \mathrm{g} / \mathrm{mL} \mathrm{Co}{ }^{2+}$; (C) exposed to $15 \mu \mathrm{g} / \mathrm{mL} \mathrm{Co} \mathrm{O}_{4} \mathrm{NPs}$; (D) caspase-3 activity.

Notes: Each value represents the mean \pm standard error of three experiments. $* P<0.01$ vs control.

Abbreviations: $\mathrm{HepG} 2$, human hepatocarcinoma; $\mathrm{Co}_{3} \mathrm{O}_{4} \mathrm{NPs}$, cobalt oxide nanoparticles; $\mathrm{Co}^{2+}$, cobalt ions.

A

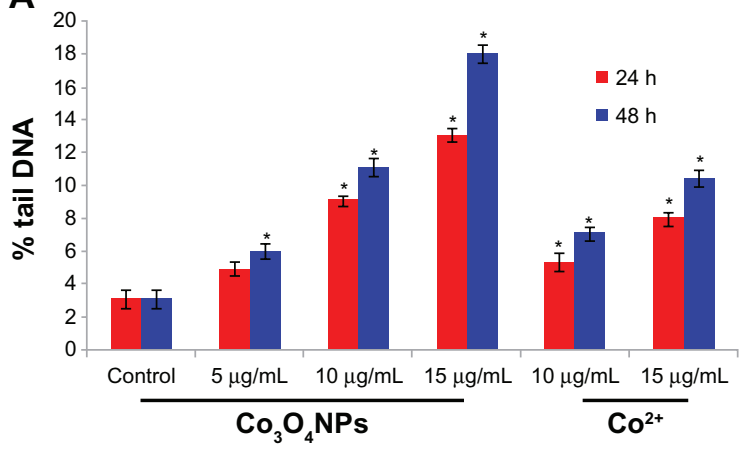

C

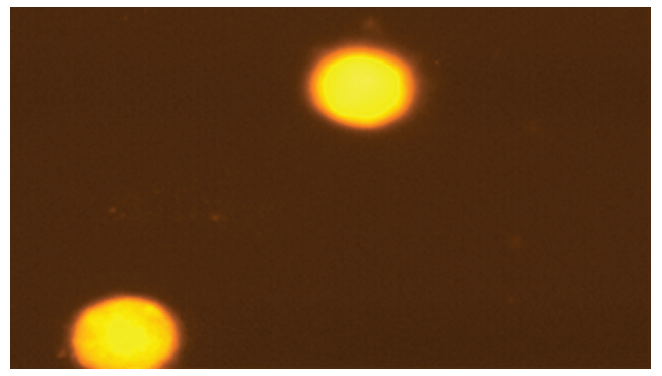

B

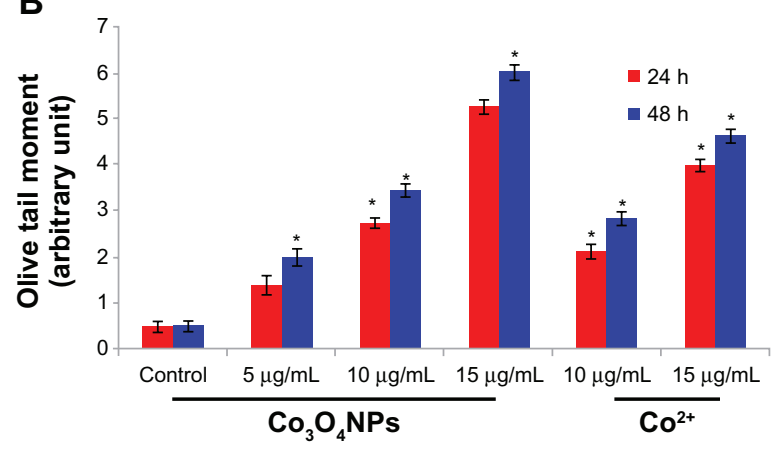

D

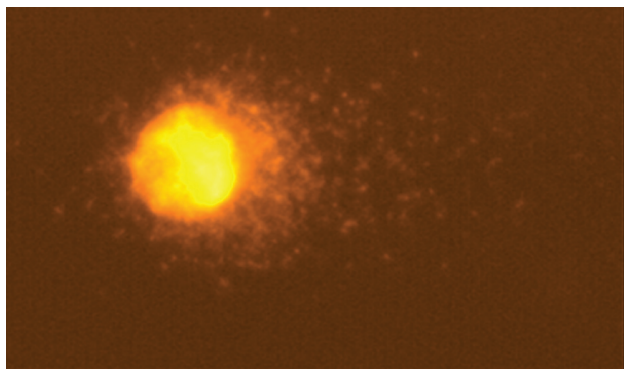

Figure 7 DNA damage in HepG2 cells after 24 hours and 48 hours of exposure to different concentrations of $\mathrm{Co}_{3} \mathrm{O}_{4} \mathrm{NPs}$ and $\mathrm{Co}^{2+}$. (A) Percentage tail DNA; (B) olive tail moment (arbitrary unit); (C) control cell; (D) exposed cell.

Notes: Each value represents the mean \pm standard error of three experiments, performed in duplicate. $* P<0.01$ vs control.

Abbreviations: $\mathrm{HepG}$, human hepatocarcinoma; $\mathrm{Co}_{3} \mathrm{O}_{4} \mathrm{NPs}$, cobalt oxide nanoparticles; $\mathrm{Co}^{2+}$, cobalt ions. 
be strongly depleted in response to nanoparticle exposure. ${ }^{34}$ SOD is specialized to convert highly superoxide radicals to less toxic $\mathrm{H}_{2} \mathrm{O}_{2}$. Higher production of intracellular ROS and membrane LPO in $\mathrm{Co}_{3} \mathrm{O}_{4} \mathrm{NP}$-exposed cells along with depletion of antioxidant components suggest that oxidative stress might be the primary mechanism for toxicity of $\mathrm{Co}_{3} \mathrm{O}_{4} \mathrm{NPs}$ in HepG2 cells. In the present study, ROS and MDA levels were significantly higher, while the antioxidant GSH level was significantly lower in HepG2 cells exposed to $\mathrm{Co}_{3} \mathrm{O}_{4} \mathrm{NPs}$. ROS, such as $\mathrm{O}^{2-}, \mathrm{OH} \bullet$ and $\mathrm{H}_{2} \mathrm{O}_{2}$ elicit a variety of physiological and cellular events, including inflammation, DNA damage, and apoptosis. ${ }^{35}$ Caspases are known to play a vital role in both initiation and execution of apoptosis, and in the present study we observed that caspase-3 levels increased in HepG2 cells after $\mathrm{Co}_{3} \mathrm{O}_{4} \mathrm{NPs}$ exposure. Caspase-3 has been reported as being essential for cellular DNA damage and apoptosis. ${ }^{36}$

Information on the effects of environmental exposure of $\mathrm{Co}_{3} \mathrm{O}_{4} \mathrm{NPs}$ to humans and potential health impacts is still lacking. The cell membrane offers an excellent barrier for most ions, and cobalt, in the ionic form, has been shown to have a lower efficiency in cell uptake. ${ }^{29}$ In our experiments, $\mathrm{Co}_{3} \mathrm{O}_{4} \mathrm{NPs}$ induced a concentration- and time-dependent impairment of DNA damage, although $\mathrm{Co}^{2+}$ showed less genotoxicity. Our results are similar to those showing that $\mathrm{Co}_{3} \mathrm{O}_{4} \mathrm{NPs}$ induce genotoxicity in human leukocytes. ${ }^{37}$ Cobalt-enhanced ROS formation oxidize proteins ${ }^{38}$ and cause oxidative DNA damage but show a neuroprotective effect on hypoxia-induced oxidative stress. ${ }^{39}$

DNA damage, apoptosis, and oxidative stress markers raise concern about the safety associated with applications of $\mathrm{Co}_{3} \mathrm{O}_{4} \mathrm{NPs}$ in consumer products. However, more in vivo studies are needed to fully understand the mechanism of $\mathrm{Co}_{3} \mathrm{O}_{4} \mathrm{NP}$ toxicity.

\section{Acknowledgment}

The authors extend their appreciation to the Deanship of Scientific Research at King Saud University for funding the work through the research group project no. RGPVPP-180.

\section{Disclosure}

The authors report no conflicts of interest in this work.

\section{References}

1. Singh N, Manshian B, Jenkins GJ, et al. Nano genotoxicology: the DNA damaging potential of engineered nanomaterials. Biomaterials. 2009;30:3891-3914.

2. Oberdorster G, Oberdorster E, Oberdorster J. Nanotoxicology: an emerging discipline evolving from studies of ultrafine particles. Environ Health Persp. 2005;113:823-839.
3. Jin CY, Zhu BS, Wang XF, Lu QH. Cytotoxicity of titanium dioxide nanoparticles in mouse fibroblast cells. Chem Res Toxicol. 2008;21: 1871-1877.

4. PEN 2009. Project of the Emerging Nanotechnologies (PEN). [webpage on the Internet]. Available at: http://www.nanotechproject.org.

5. Mandal S, Phadtare S, Sastry M. Interfacing biology with nanoparticles. Curr App Phys. 2005;5:118-127.

6. ATSDR. Public health assessments completed. Agency for Toxic Substances and Disease Registry (ATSDR), Department of Health and Human Services (HHS). Notice Fed Regist. 1999;64:4422-4423.

7. De Boeck M, Lombaert N, De Backer S, Finsy R, Lison D, KirschVolders M. In vitro genotoxic effects of different combinations of cobalt and metallic carbide particles. Mutagenesis. 2003;18: 177-186.

8. Lison D, Carbonnelle P, Mollo L, Lauwerys R, Fubini B. Physicochemical mechanism of the interaction between cobalt metal and carbide particles to generate toxic activated oxygen species. Chem Res Toxicol. 1995;8:600-606.

9. Patlolla A, Patlolla B, Tchounwou P. Evaluation of cell viability, DNA damage, and cell death in normal human dermal fibroblast cells induced by functionalized multi walled carbon nanotube. Mo Cell Biochem. 2010;338:225-232.

10. Jan E, Byrne SJ, Cuddihy M, et al. High-content screening as a universal tool for fingerprinting of cytotoxicity of nanoparticles. ACS Nano. 2008;2:928-938.

11. Nel A, Xia T, Madler L, Li N. Toxic potential of materials at the nanolevel. Science. 2006;311:622-627.

12. Murdock RC, Braydich-Stolle L, Schrand AM, Schlager JJ, Hussain SM. Characterization of nanomaterial dispersion in solution prior to in vitro exposure using dynamic light scattering technique. Toxicol Sci. 2007;101:239-253.

13. Mossman T. Rapid colorimetric assay for cellular growth and survival: application to proliferation and cytotoxicity assays. J Immunol Meth. 1983;65:55-63.

14. Wroblewski F, LaDue JS. Lactate dehydrogenase activity in blood. Pro of the Soc for Experim Biol and Med. 1955;90:210-213.

15. Wang H, Joseph JA. Quantifying cellular oxidative stress by dichlorofluorescein assayusing microplate reader. Free Radic Biol Med. 1999;27:612-616.

16. Bradford MM. A rapid and sensitive method for the quantization of microgram quantities of protein utilizing the principle of protein-dye binding. Anal Biochem. 1976;72:248-254.

17. Ohkawa H, Ohishi N, Yagi K. Assay for lipid peroxides in animal tissues bythiobarbituric acid reaction. Anal Biochem. 1979;95: 351-358.

18. Ellman G. Tissue sulfhydryl groups. Arch Biochem Biophys. 1959;82: 70-77.

19. Kakkar PS, Das B, Viswanathan PN. A modified spectrophotometric assay of superoxide dismutase. Ind J Biochem Biophys. 1984;21: 130-132.

20. Sinha AK. Colorimetric assay of catalase. Anal Biochem. 1972;47: 389-394.

21. Dhar-Mascareno M, Carcamo JM, Golde DW. Hypoxia-reoxygenationinduced mitochondrial damage and apoptosis in human endothelial cells are inhibited by vitamin C. Free Radic Bio Med. 2005;38: 1311-1322.

22. Singh NP, McCoy MT, Tice RR, Schneider EL. A simple technique for quantization of low levels of DNA damage in individual cells. Exp Cell Res. 1988;175:184-191.

23. Ali D, Ray RS, Hans RK. UVA-induced cyototoxicity and DNA damaging potential of Benz (e) acephenanthrylene in human skin cell line. Toxicology Letters. 2010;199(2):193-200.

24. Anderson D, Yu TW, Phillips BJ, Schmerzer P. The effect of various antioxidants and other modifying agents on oxygen-radical generated DNA damage inhuman lymphocytes in the comet assay. Mutat Res. 1994;307:261-271.

25. Papis E, Rossi F, Raspanti M, et al. Engineered cobalt oxide nanoparticles readily enter cells. Toxicol. Lett. 2009;189:253-259.

26. Liu X, Qiu G, Li X. Shape-controlled synthesis and properties of uniform spinel cobalt oxide nanotubes. Nanotechnology. 2005;16:3035-3040. 
27. Zou J, Chen Q, Jin X, et al. Olaquindox induces apoptosis through the mitochondrial pathway in HepG2 cells. Toxicology. 2011;285: 104-133.

28. Horev-Azaria L, Kirkpatrick CJ, Korenstein R, et al. Predictive toxicology of cobalt nanoparticles and ions: comparative in vitro study of different cellular models using methods of knowledge discovery from data. Toxicol Sci. 2011;122 (2):489-501.

29. Colognato R, Bonelli A, Bonacchi D, Baldi G, Migliore L. Analysis of cobalt ferrite nanoparticles induced genotoxicity on human peripheral lymphocytes: comparison of size and organic grafting-dependent effects. Nanotox. 2007;1(4):301-308.

30. Mahmoudi M, Simchi A, Milani AS, Stroeve P. Cell toxicity of super paramagnetic iron oxide nanoparticles. J Colloid Interface Sci. 2009;336:510-518.

31. Barillet S, Jugan ML, Laye M, et al. In vitro evaluation of SiC nanoparticles impact on A549 pulmonary cells: cyto-, genotoxicity and oxidative stress. Toxicol Lett. 2010;198:324-330.

32. Wise JP, Goodale BC, Wise SS. Silver nanospheres are cytotoxic and genotoxicto fish cells. Aquat Toxicol. 2010;97:34-41.
33. Ott M, Gogvadze V, Orrenius S, Zhivotovsky B. Mitochondria, oxidative stress and cell death. Apoptosis. 2007;12:913-922.

34. Rana SV. Metals and apoptosis: recent developments. J Trace Elem Med Biol. 2008;22:262-284.

35. Asharani PV, Mun GK, Hande MP, Valiyaveettil S. Cytotoxicity and genotoxicity of silver nanoparticles in human cells. ACS Nano. 2009;3: 279-290.

36. Janicke RU, Sprengart ML, Wati MR, Porter AG. Caspase-3 is required for DNA fragmentation and morphological changes associated with apoptosis. J Biol Chem. 1998;273:9357-9360.

37. Colognato R, Bonelli A, Ponti J, et al. Comparative genotoxicity of cobalt nanoparticles and ions on human peripheral leukocytes in vitro. Mutagen. 2008;23:377-382.

38. Petit A, Mwale F, Tkaczyk C, Antoniou J, Zukor DJ, Huk OL. Induction of protein oxidation by cobalt and chromium ions in human U937 macrophages. Biomaterials. 2005;26:4416-4422.

39. Shrivastava K, Shukla D, Bansal A, Sairam M, Banerjee PK, Ilavazhagan G. Neuroprotective effect of cobalt chloride on hypobaric hypoxia-induced oxidative stress. Neurochem Int. 2008;52:368-375.
International Journal of Nanomedicine

\section{Publish your work in this journal}

The International Journal of Nanomedicine is an international, peerreviewed journal focusing on the application of nanotechnology in diagnostics, therapeutics, and drug delivery systems throughout the biomedical field. This journal is indexed on PubMed Central,

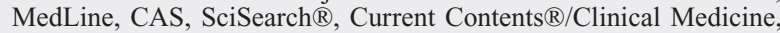

\section{Dovepress}

Journal Citation Reports/Science Edition, EMBase, Scopus and the Elsevier Bibliographic databases. The manuscript management system is completely online and includes a very quick and fair peer-review system, which is all easy to use. Visit http://www.dovepress.com/ testimonials.php to read real quotes from published authors. 